B.R. McNeill MD FRCPC, J.M. Murkin MD FRCPC, J.K. Farrar PhD, A.W. Gelb MBChB FRCPC

\title{
Autoregulation and the $\mathrm{CO}_{2}$ responsiveness of cerebral blood flow after cardiopulmonary bypass
}

Cerebral blood flow (CBF) was measured by ${ }^{133} \mathrm{Xe}$ clearance to determine whether there were any residual effects of cardiopulmonary bypass (CPB) on the $C B F$ response to changes in arterial $\mathrm{PCO}_{2}$ or blood pressure in the early $(3-8 \mathrm{hr})$ post-CPB period. During $C P B$, the nine patients studied were managed according to alpha-stat, temperature uncorrected, $\mathrm{pH}$ management. The mean $\pm S D$ increase in $C B F$ resulting from an increase in $\mathrm{PaCO}_{2}\left(1.35 \pm 0.5 \mathrm{ml} \cdot 100 \mathrm{~g}^{-1} \cdot \mathrm{min}^{-1} \cdot \mathrm{mmHg}^{-1}\right.$ $\mathrm{PaCO}_{2}$ ) was within the normal range, indicating appropriate $C B F$ response to a change in $\mathrm{PaCO}_{2}$. There were no significant differences in $C B F$, being $25.7 \mathrm{ml} \cdot 100 \mathrm{~g}^{-1} \cdot \mathrm{min}^{-1}$ at a mean arterial blood pressure of $70 \mathrm{mmHg}$ and $26.5 \mathrm{ml} .100 \mathrm{~g}^{-1} \cdot \mathrm{min}^{-1}$ at $110 \mathrm{mmHg}$, demonstrating intact cerebral autoregulation over this pressure range. We conclude that cerebral autoregulation and $\mathrm{CO}_{2}$ responsiveness are preserved in the immediate postoperative period after $C P B$ using alpha-stat $p H$ management.

Le flot sanguin cérébral (CBF) a été mesuré par $X e^{133}$ afin de déterminer les effets résiduels de la circulation extracorporelle (CPB) sur les réponses due CBF aux changements de la $\mathrm{PCO}_{2}$ ou de la pression artérielle dans la période précoce en post $C P B$ (3-8 hres). Durant le CPB, les neuf patients étudiés et chez qui le pH ne fut pas corrigé selon la température, l'augmentation

\section{Key words}

ANAESTHESIA: cardiovascular;

BRAIN: blood flow, autoregulation;

SURGERY: cardiovascular, cardiopulmonary bypass.

From the Departments of Anaesthesia and Clinical Neurological Sciences, University Hospital, University of Western Ontario, London, Ontario, Canada.

Address correspondence to: Dr. J. M. Murkin, Department of Anaesthesia, University Hospital, 339 Windermere Rd., London, Ontario N6A SA5.

Presented in part at the 1989 Annual Meeting of the Canadian Anaesthetists' Society in Ottawa, Ontario. Supported in part by PSI grant no. 88-25. moyenne $\pm S D$ de la $C B F$ après une augmentation de la $\mathrm{PaCO}$ $\left(1,35 \pm 0,5 \mathrm{ml} \cdot 100 \mathrm{gm}^{-1} \cdot \mathrm{min}^{-1} \cdot \mathrm{mmHg}^{-1} \mathrm{PaCO}_{2}\right)$ était à l'intérieur des normes indiquant une réponse appropriée du $\mathrm{CBF}$ au changement de la $\mathrm{PaCO}$. Il n'y avait aucune différence significative dans le CBF, étant $25.7 \mathrm{ml} \cdot 100 \mathrm{~g}^{-1} \cdot \mathrm{min}^{-1}$ pour des pressions artérielles moyennes de $70 \mathrm{mmHg}$ et $26,5 \mathrm{ml} \cdot 100$ $\mathrm{g}^{-1} \mathrm{~min}^{-1}$ à $110 \mathrm{mmHg}$, démontrant une autorégulation cérébrale intacte pour cet écart de pression. On conclut que l'autorégulation cérébrale et la réponse au $\mathrm{CO}_{2}$ est préservée dans la période postopératoire immédiate après CPB utilisant la conduite alpha-stat du $\mathrm{pH}$.

Central nervous system (CNS) dysfunction following cardiopulmonary bypass (CPB) has been reported to occur in most patients in the early postoperative period, with new neurological signs demonstrable in approximately two-thirds of them. ${ }^{1.2}$ Although most of the abnormalities are transient and non-disabling, they are often present at the time of discharge from hospital. ' At this time, clinically obvious stroke is found in five per cent and severe disability in one to two per cent of patients. ${ }^{1,3}$

In a prospective study, Smith et al. ${ }^{2}$ demonstrated a significant increase in (signs of) CNS dysfunction at $24 \mathrm{hr}$ after CPB, but no significant differences in the incidence of CNS dysfunction at eight days or eight weeks compared with controls undergoing major vascular or thoracic procedures. Cerebral blood flow (CBF), however, was only measured on the latter two occasions and was no different from controls. In another study, CBF was shown to be reduced on the fourth and eighth day following CPB with the greatest reductions occurring at the earlier measurement period. ${ }^{4}$

These results may indicate a window of vulnerability of the CNS in the early post-CPB period. This time may also be associated with marked swings in blood pressure or $\mathrm{PaCO}_{2}$. If $\mathrm{CBF}$ autoregulation were deranged, such swings could result in large changes in CBF that may contribute to postoperative neurological dysfunction. 
Cerebral autoregulation and $\mathrm{CO}_{2}$ responsiveness have not been systematically investigated in man during the early post-CPB period. The aim of this study was to evaluate prospectively $\mathrm{CBF}$ autoregulation and $\mathrm{CO}_{2}$ responsiveness at this time.

\section{Methods}

Following institutional approval and after obtaining written informed consent, nine patients undergoing elective cardiac surgery were anaesthetized with an air- $\mathrm{O}_{2-}$ narcotic-relaxant technique (sufentanil 7-22 $\mu \mathrm{g}^{-1}$, or fentanyl $20-49 \mu \mathrm{g} \cdot \mathrm{kg}^{-1}$ and $50-100$ per cent $\mathrm{O}_{2}$ ) and supplemental benzodiazepines (diazepam 0.12-0.25 $\mathrm{mg} \cdot \mathrm{kg}^{-1}$, lorazepam $0.10 \mathrm{mg} \cdot \mathrm{kg}^{-1}$, or midazolam 0.1 $\mathrm{mg} \cdot \mathrm{kg}^{-1}$ ). All patients had received their chronic antianginal medications in addition to a preoperative narcotic sedative (morphine $0.12 \mathrm{mg} \cdot \mathrm{kg}^{-1}$, lorazepam 0.02-0.06 $\left.\mathrm{mg} \cdot \mathrm{kg}^{-1}\right)$.

During CPB, nonpulsatile perfusion was conducted at rates of $2.0-2.5 \mathrm{~L} \cdot \mathrm{m}^{-2} \cdot \mathrm{min}^{-1}$ using a membrane oxygenator (Cobe $\mathrm{CML}$ ) and a 20 -micron arterial line filter. Hypothermia $\left(26^{\circ}-28^{\circ} \mathrm{C}\right)$ was induced in eight patients during $\mathrm{CPB}$, one patient remaining normothermic. Mean arterial pressure (MAP) was maintained greater than $\mathbf{5 0}$ $\mathrm{mmHg}$ and arterial blood gases were regulated according to alpha-stat (temperature uncorrected) $\mathrm{pH}$ management. ${ }^{5}$ Of the nine patients, eight underwent coronary artery bypass grafting while the normothermic CPB patient underwent closed-chamber accessory pathway cryoablation. ${ }^{6}$

No patient with autonomic dysfunction, e.g., insulindependent diabetes, uncontrolled hypertension (diastolic BP $>100 \mathrm{mmHg}$ ), or those with poor left ventricular function were included in the study. Postoperatively, patients were excluded if there was ongoing myocardial ischaemia or haemodynamic instability requiring inotropes or vasodilators. Patients receiving infusions of nitroglycerin of less then $1 \mu \mathrm{g} \cdot \mathrm{kg}^{-1} \cdot \mathrm{min}^{-1}$ were included provided the dose did not fluctuate during the study period.

Cerebral blood flow was determined from the averaged clearance of ${ }^{133} \mathrm{Xe}$ measured by ten external scintillation detectors, five located over each cerebral hemisphere (Novo Diagnostics 10a Cerebrograph). ${ }^{7}$ Approximately five $\mathrm{mCi}$ of ${ }^{133} \mathrm{Xe}$ in $6 \mathrm{ml}$ saline was injected intravenously for each determination. End-tidal respiratory gas sampling was used to correct for recirculation. The resulting ${ }^{133} \mathrm{Xe}$ clearance curves were assessed by noncompartmental height-over-area analysis. ${ }^{8}$ As this represents the mean flow of all tissue under the detector, the curve was integrated to $15 \mathrm{~min}$ rather than infinity to reduce the effect of the extracerebral component. ${ }^{9}$ Standard correction factors were used to compensate for changes in the xenon partition coefficient due to alterations in temperature and haematocrit. ${ }^{10}$

All CBF determinations took place in the intensive care unit three to eight hours after termination of CPB. Each CBF measurement required approximately $13 \mathrm{~min}$ for completion of data acquisition. The study was divided into two parts, each assessing either cerebral autoregulation or $\mathrm{CO}_{2}$ responsiveness, each patient being randomly assigned as to which segment was done first.

Cerebral $\mathrm{CO}_{2}$ responsiveness was assessed by first measuring baseline $\mathrm{CBF}$ at $\mathrm{PaCO}_{2} 40 \mathrm{mmHg}\left(\mathrm{CO}_{2}\right.$ Base 1), following which $\mathrm{PaCO}_{2}$ was increased $10 \mathrm{mmHg}$ and $\mathrm{CBF}$ remeasured (high $\mathrm{CO}_{2}$ ). The $\mathrm{PaCO}_{2}$ was then returned to $40 \mathrm{mmHg}$ and $\mathrm{CBF}$ was again measured $\left(\mathrm{CO}_{2}\right.$ base 2).

For assessment of cerebral autoregulation, $\mathrm{CBF}$ was measured initially (MAP base 1), blood pressure was then increased to mean arterial pressure (MAP) $110 \mathrm{mmHg}$ and CBF was remeasured (MAP 110), after which MAP was reduced to $70 \mathrm{mmHg}$ and CBF again measured (MAP 70). Following this, MAP was allowed to return to control levels and $\mathrm{CBF}$ measurements repeated (MAP base 2).

Arterial $\mathrm{PCO}_{2}$, rectal temperature, mean arterial pressure and haemoglobin concentration were measured during each $\mathrm{CBF}$ determination. For assessment of $\mathrm{CO}_{2}$ responsiveness, $\mathrm{PaCO}_{2}$ was monitored using a capnometer (Hewlett Packard 47210A) and was varied by changing minute ventilation while MAP was varied using phenylephrine and trimethaphan infusions for assessment of cerebral autoregulation. In both parts of the study, base 2 represented a post-intervention control measurement.

All data were analysed by repeated measures analysis of variance (ANOVA) and Scheffe's test comparing each measurement against the other. Results that did not attain significance were subjected to power analysis. Alpha of $<0.05$ and beta of 0.20 were used as measures of significance.

\section{Results}

All patients in the study underwent surgery and CPB which averaged $99 \pm 27 \mathrm{~min}$ without incident. Due to time constraints, both parts of the study protocol were performed in only seven of the nine patients, with the other two patients each completing one of the autoregulation or $\mathrm{CO}_{2}$ responsiveness parts (Table). Of the eight patients undergoing the $\mathrm{CO}_{2}$ responsiveness investigation, a complete set of three satisfactory CBF measurements was collected in only six patients. Base $2 \mathrm{CBF}$ measurements were excluded in two patients due to unsatisfactory ${ }^{133} \mathrm{Xe}$ clearance curves related to high background activity. A CBF response to elevated $\mathrm{PaCO}_{2}$ 


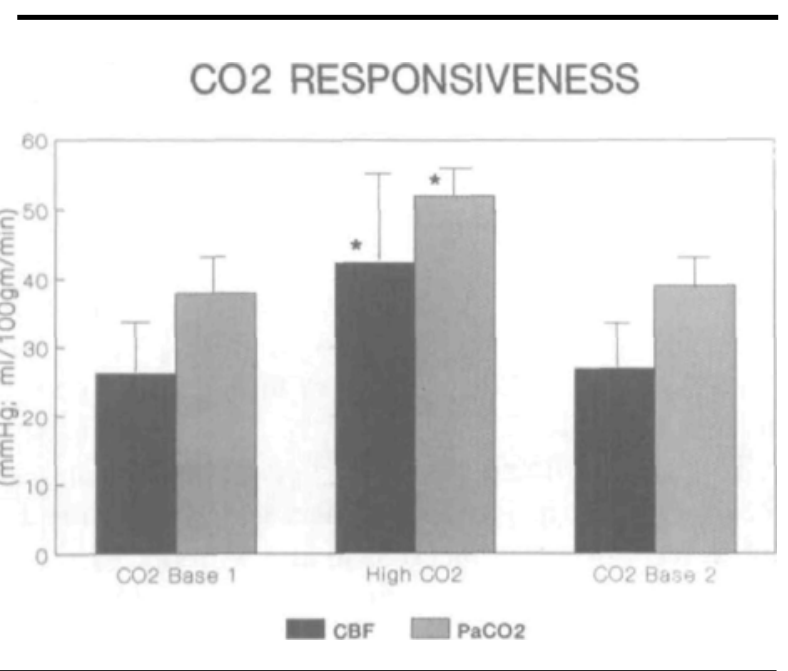

FIGURE I Cerebral blood flow (CBF) responsiveness to increases in $\mathrm{PaCO}_{2}$ measured in six patients after cardiopulmonary bypass. A significant increase in $\mathrm{PaCO}_{2}$ resulted in a concomitant elevation of $\mathrm{CBF}$ (high $\mathrm{CO}_{2}$ ) that returned to basal levels with the restoration of normal levels of $\mathrm{PaCO}_{2}\left(\mathrm{CO}_{2}\right.$ base 2$)$.

$* P<0.05$ vs MAP base $\mathrm{I}$.

was measured in all eight patients and this was used to calculate cerebral $\mathrm{CO}_{2}$ reactivity.

The patients studied were all males of mean age $56 \mathrm{yr}$ (range 45 to $68 \mathrm{yr}$ ). There were no significant complications during the study period, all patients making uneventful recoveries from surgery, though the incidence of CNS dysfunction during the postoperative period was not specifically investigated.

The normothermic CPB patient did not behave differently from the group as a whole in either the $\mathrm{CO}_{2}$ responsiveness or autoregulation parts of the study and was thus included in the analysis.

\section{$\mathrm{CO}_{2}$ responsiveness}

In the eight patients studied, the increase in $\mathrm{CBF}$ in response to increases in $\mathrm{PaCO}_{2}$ averaged $1.35 \pm 0.5$

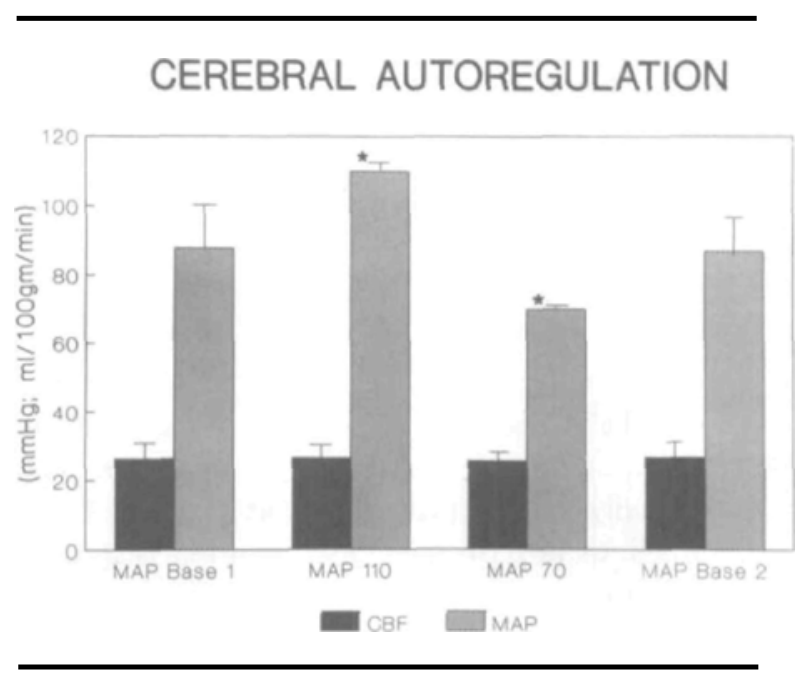

FIGURE 2 Cerebral blood flow (CBF) and meun arterial pressure (MAP) measured in eight patients after cardiopulmonary bypass.

There was no significant change in $\mathrm{CBF}$ at any point despite significant changes in MAP (MAP 110, MAP 70).

${ }^{*} P<0.05$ vs $\mathrm{CO}_{2}$ base 1 .

$\mathrm{ml} \cdot 100 \mathrm{~g}^{-1} \cdot \mathrm{min}^{-1} \cdot \mathrm{mmHg} \mathrm{PaCO}_{2}^{-1}$ (range $0.82-2.41$ $\mathrm{ml} \cdot 100 \mathrm{~g}^{-1} \cdot \mathrm{min}^{-1} \cdot \mathrm{mmHg} \mathrm{PaCO}_{2}^{-1}$, demonstrating intact cerebral $\mathrm{CO}_{2}$ responsiveness. In the six patients in whom $\mathrm{CO}_{2}$ base $2 \mathrm{CBF}$ measurements were obtained, despite the significant increase in $\mathrm{CBF}$ associated with the elevated $\mathrm{PaCO}_{2}$, no significant difference in $\mathrm{CBF}$ measurements between the $\mathrm{CO}_{2}$ base $\mathrm{I}$ and $\mathrm{CO}_{2}$ base 2 were found (Figure I).

\section{Autoregulation}

The eight patients in whom data were obtained in response to MAP variation showed no significant difference in CBF between the MAP $110 \mathrm{mmHg}$, MAP $70 \mathrm{mmHg}$, or the two baseline measurements, despite significant differences in MAP (Figure 2). Intact cerebral autoregulation over the range MAP $70-110 \mathrm{mmHg}$ was thus demonstrated.

TABLE $($ Mean \pm SD)

\begin{tabular}{|c|c|c|c|c|c|c|c|}
\hline & \multicolumn{3}{|c|}{$\mathrm{CO}_{2}$ Responsiveness } & \multicolumn{4}{|c|}{ MAP autoregulation } \\
\hline & $\begin{array}{l}\mathrm{CO}_{2} \\
\text { Base I }\end{array}$ & $\begin{array}{l}\mathrm{High} \\
\mathrm{CO}_{2}\end{array}$ & $\begin{array}{l}\mathrm{CO}_{2} \\
\text { Base } 2\end{array}$ & $\begin{array}{l}\text { MAP } \\
\text { Base } 1\end{array}$ & MAP 110 & $M A P 70$ & $\begin{array}{l}\text { MAP } \\
\text { Base } 2\end{array}$ \\
\hline$n$ (patients) & 6 & 6 & 6 & 8 & 8 & 8 & 8 \\
\hline $\mathrm{Hb}\left(\mathrm{g} \cdot \mathrm{dl}^{-1}\right)$ & $10 . B=1.8$ & $10.0 \pm 1.9$ & $9.9 \pm 2.0$ & $10.4 \pm 2.4$ & $10.4 \pm 2.4$ & $10.2 \pm 2.5$ & $10.0 \pm 2.6^{*}$ \\
\hline Rectal Temp. $\left({ }^{\circ} \mathrm{C}\right)$ & $35.7 \pm 0.6$ & $35.8=0.7$ & $35.9 \pm 0.6^{*}$ & $36.3 \pm 1.0$ & $36.4 \pm 1.0$ & $36.5 \pm 1.0^{*}$ & $36.6 \pm 1.0^{*}+$ \\
\hline MAP $\left(\mathrm{mmH}_{\mathrm{m}}\right)$ & $84 \pm 12$ & $81 \pm 7$ & $87 \pm 10$ & $94 \pm 15$ & $111 \pm 2^{*}$ & $71 \pm 1^{*}, \dagger$ & $90 \pm 8 \%, \ddagger$ \\
\hline $\mathrm{PaCO}_{2}\left(\mathrm{mmH}_{\mathrm{B}}\right)$ & $38 \pm 4$ & $52 \pm 3^{*}$ & $39 \pm 4$ & $40 \pm 5$ & $39 \pm 4$ & $39 \pm 4$ & $39 \pm 4$ \\
\hline $\operatorname{CBF}\left(\mathrm{ml} \cdot 100 \mathrm{~g}^{-1} \cdot \min \right)$ & $26.2 \pm 6.9$ & $42.4 \pm 14^{*}$ & $26.9 \pm 6.68$ & $26.3 \pm 7.2$ & $26.5 \pm 6.3$ & $25.7 \pm 5.4$ & $26.7 \pm 6.8$ \\
\hline
\end{tabular}

${ }^{*} P<0.05$ vs Base $\mathrm{I}_{;} \dagger P<0.05$ vs MAP $110 ; \ddagger P<0.05$ vs MAP 70; $\$ P<0.05$ vs high $\mathrm{CO}_{7}$. 


\section{Discussion}

It is increasingly apparent that subtle neurological dysfunction occurs post-CPB despite the low ( $1-2$ per cent) incidence of severe disability. ${ }^{1,3}$ In 312 patients who underwent $\mathrm{CPB}$, Shaw et al. ${ }^{1}$ were able to detect new neurological changes in 61 per cent of patients postoperatively. Although these changes were mostly minor and non-disabling, some were of more importance, e.g., development of primitive reflexes (three per cent), ophthalmological abnormalities ( 25 per cent), stroke (five per cent). At the time of discharge from hospital they had resolved in only four per cent of patients.

Abnormalities in CBF have also been reported after CPB. Henriksen et al. ${ }^{4}$ measured CBF preoperatively and on the fourth and eighth postoperative days in 14 patients undergoing $\mathrm{CPB}$. There was a significant decrease in CBF from $55.3 \mathrm{ml} \cdot 100 \mathrm{~g}^{-1} \cdot \mathrm{min}^{-1}$ preoperatively, to $43.5 \mathrm{ml} \cdot 100 \mathrm{~g}^{-1} \cdot \mathrm{min}^{-1}$ on the fourth day and $47.8 \mathrm{ml} \cdot 100 \mathrm{~g}^{-1} \cdot \mathrm{min}^{-1}$ on the eighth day. In the 11 patients investigated, measurements one year later remained slightly lower (one per cent) in the CPB group. There was no significant change in postoperative $C B F$ in a control group of 15 patients undergoing cerebrovascular surgery.

In a study by Smith et al., ${ }^{2} 55$ patients undergoing CPB and a control group of 20 patients having thoracic or major vascular surgery were investigated. Preoperatively, and at eight days and eight weeks postoperatively, CBF, neuropsychological status, and neurological signs were assessed. The latter were also assessed $24 \mathrm{hr}$ postoperatively. Only at $24 \mathrm{hr}$ postoperatively was the incidence of neurological signs in the CPB group significantly increased relative to controls. The slight decrease observed in postoperative CBF in the CPB group did not achieve statistical significance.

Despite the low incidence of severe disability, evidence is mounting that CPB causes subtle disturbances in the CNS. the early postoperative period may be associated with marked swings in blood pressure or $\mathrm{PaCO}_{2}$. If $\mathrm{CBF}$ regulation were deranged, such swings could result in large changes in CBF that could contribute to postoperative neurological dysfunction.

We have found CBF to show an appropriate increase in response to changes in $\mathrm{PaCO}_{2}\left(1.35 \mathrm{ml} \cdot 100 \mathrm{~g}^{-1} \cdot \mathrm{min}^{-1}\right.$. $\mathrm{mmHg}^{-1}$ ). This is consistent with previously published results (range $0.43-2.17 \mathrm{ml} \cdot 100 \quad \mathrm{~g}^{-1} \cdot \mathrm{mmHg}$ $\mathrm{PaCO}_{2}{ }^{-1}$ ). ${ }^{11-16}$ Similarly, CBF autoregulation over the range of MAP 70-110 $\mathrm{mmHg}$ appears to be well maintained during the early post-CPB period.

Because of the relatively small number of patients involved in this study, a 38 per cent change in CBF was required in order to demonstrate a statistically significant change in CBF. However, if autoregulation was im- paired, the observed 57 per cent change in MAP should have been of sufficient magnitude to produce a significant change in CBF since in a previous study, in which pressure passive $\mathrm{CBF}$ was detected in patients managed using $\mathrm{pH}$-stat $\mathrm{pH}$ management, a 40 per cent change in MAP produced a 45 per cent change in $C B F{ }^{5}$ The lack of difference in CBF between base 1 and base 2 measurements, despite interim increases in $\mathrm{PaCO}_{2}, \mathrm{MAP}$, or $\mathrm{CBF}$, demonstrated the stability of these patients during the study period.

The use of trimethaphan as a hypotensive agent was predicated upon its absence of effect on CBF. ${ }^{17}$ Trimethaphan has direct peripheral vasodilating properities and may in addition cause histamine release. ${ }^{17.18}$ This could theoretically increase CBF but numerous studies have shown that trimethaphan does not directly increase CBF. ${ }^{17,19}$

Phenylephrine, by a direct vasoconstricting action, could have masked an increase in CBF at the higher MAP studied, but there is evidence to suggest that this does not usually occur. ${ }^{20}$ Intravascular catecholamines do not have direct effects on the cerebral vasculature ${ }^{21}$ as they do not cross the blood brain barrier. ${ }^{22}$ It is agents with betaagonist activity that have been shown to increase CBF, although this is presumably secondary to an increase in $\mathrm{CMRO}_{2}{ }^{23}$ The small reduction in CBF occasionally noted with alpha-agonists such as phenylephrine ${ }^{24}$ presumably reflects cerebral vasoconstriction in response to the marked hypertension produced. ${ }^{19}$

All the patients investigated were unconscious postoperatively, thus the relatively low CBF values (approximately $26 \mathrm{ml} \cdot 100 \mathrm{~g}^{-1} \cdot \mathrm{min}^{-1}$ ) presumably reflect residual anaesthesia in the early post-CPB period. These values are similar to those reported by investigators using similar ${ }^{133} \mathrm{Xe}$ clearance techniques in subjects during fentanyldiazepam anaesthesia. 5,25

A potentially important consideration is our use of alpha-stat (temperature uncorrected), as opposed to $\mathrm{pH}$ stat (temperature corrected), blood gas management during $\mathrm{CPB}$. We have previously demonstrated normal CBF autoregulation and intact flow/metabolism coupling during hypothermic $\mathrm{CPB}$ managed by alpha-stat $\mathrm{pH}$ management. ${ }^{5}$ It was also shown that $\mathrm{pH}$-stat management resulted in loss of CBF autoregulation with CBF becoming pressure passive. ${ }^{5}$ Whether cerebral autoregulation and $\mathrm{CO}_{2}$ responsiveness are maintained postoperatively if $\mathrm{pH}$-stat management is employed during CPB has not been investigated.

Our results, obtained after $\mathrm{CPB}$ using alpha-stat $\mathrm{pH}$ management, demonstrate normal cerebral $\mathrm{CO}_{2}$ responsiveness and intact cerebral autoregulation over MAP $70-110 \mathrm{mmHg}$ in the early post-CPB period. It is thus unlikely that primary postoperative derangements of 
cerebral autoregulation are instrumental in the genesis of neurological dysfunction in patients undergoing $\mathrm{CPB}$ with alpha-stat $\mathrm{pH}$ management.

\section{Acknowledgements}

Supported in part by the financial assistance of the physicians of Ontario through the P.S.I. Foundation.

\section{References}

1 Shaw PJ, Bates D, Cartlidge NEF, Heaviside D, Julian $D G$, Shaw DA. Early neurologic complications of coronary artery bypass surgery. Br Med J 1985; 291 : 1384- 7.

2 Smith PLC, Treasure T, Newman SP et al. Cerebral consequences of cardiopulmonary bypass. Lancet 1986; i: 823-5.

3 Breuer AC, Furlan AJ, Hanson MR et al. Central nervous systcm complications of coronary artery bypass graft surgery: prospective analysis of 421 patients. Stroke 1983; 14: 682-7.

4 Henriksen L. Evidence suggestive of diffuse brain damage following cardiac operations. Lancet 1984 ; i: 816-20.

5 Murkin JM, Farrar JK, Tweed WA, McKenzie FN, Guiraudon $G$. Cerebral autoregulation and flow/ metabolism coupling during cardiopulmonary bypass: the influence of $\mathrm{PaCO}_{2}$. Anesth Analg 1987; 66: 825-3.

6 Irish CL, Murkin JM. Guiraudon GM. Anaesthetic management for surgical cryoablation of accessory conducting pathways: a review and report of 181 cases. Can J Anaesth 1988; 35: 634-40.

7 Murkin JM. Appendix: CBF methodology. In: Hilberman $M(E d$.$) . Brain Injury and Protection During Heart$ Surgery. Boston: Martinus Nijhoff Publishing, 1988: 61-6.

8 Hoedt-Rasmussen $K$, Sveinsdoftir E, Lassen NA. Regional cerebral blood flow in man determined by intra-arterial injection of radioactive inert gas. Circ Res 1966; 18: 237-47.

9 Obrist WD, Wilkinson WE. Stability and sensitivity of CBF indices of the noninvasive ${ }^{133} \mathrm{Xe}$ method. In: Hartman A, Hoyer S (Eds.). Cerebral Blood Flow and Metabolism Measurement. New York: Springer-Verlag 1985: 30-6.

10 Chen RYZ, Fan FC, Kim S, Jan KM, Usami S, Chien $S$. Tissue-blood partition coefficient for xenon: temperature and hematocrit dependence. J Appl Physiol 1980; 49: 178-83.

11 Grubb RL, Raichle ME, Eichling JO, Ter-Pogossian $M M$. The effects of changes in $\mathrm{PaCO}_{2}$ on cerebral blood volume. Stroke 1974; 5: 630-4.

12 Prough DS, Stump DA, Roy RC et al. Response of cerebral blood flow to changes in carbon dioxide tension during hypothermic cardiopulmonary bypass. Anesthesiology 1986; 64: 576-81.
13 Cold GE, Christensen KJS, Nordentoft J, Engberg M, Pedersen MB. Cerebral blood flow, cerebral metabolic rate of oxygen and relative $\mathrm{CO}_{2}$ reactivity during neuroleptanaesthesia in patients subjected to craniotomy for supratentorial cerebral tumours. Acta Anacsthesiol Scand 1988; 32: 310-5.

14 Kety SS, Schmidt DF. The effects of altered arterial tensions of carbon dioxide and oxygen on cerebral blood flow and cerebral oxygen consumption of normal young men. J Clin Invest 1948, 27: 484-92.

15 Kety SS, Schmidt CF. The effects of active and passive hyperventilation on cerebral blood flow, cerebral oxygen consumption, cardiac output, and blood pressure of normal young men. J Clin Invest 1946; 25: 197-219.

16 Wollman H, Smith TC, Stephen GW et al. Effects of extremes of respiratory and metabolic alkalosis on cerebral blood flow in man. J Appl Physiol 1968; 24: 60-5.

17 Grubb RL, Raichle ME. Effects of hemorrhagic and pharmacologic hypotension on cerebral oxygen utilization and blood flow. Anesthesiology 1982; 56: 3-8.

18 Wang HH, Liv LMP, Katz RL. A comparison of the cardiovascular effects of sodium nitroprusside and trimethaphan. Anesthesiology 1977; 46: 40-8.

19 Moyer JH, Morris G, Snyder H. A comparison of the ccrebral hemodynamic response to aramine and norepinephrine in the normotensive and hypotensive subjects. Circulation 1954; 10: 265-70.

20 Mutch WAC, Louise AM, Ringaert KRA. Phenylephrine increases regional cerebral blood flow following hemorrhage during isoflurane-oxygen anesthesia. Ancsthesiology 1989; 70: 276-9.

21 Greenfield JC, Tindall GT. Studies of the effects of vasopressor drugs on internal carotid blood flow in man In: Bain WH, Harper AM (Eds.). Blood Flow Through Organs and Tissues, Edinburgh: Livingstone, 1968; 336-48.

22 Weil-Malherbe $H$, Axelrod $H$, Tomchick $K$. Blood-brain barrier for adrenaline. Science 1958; 129: 1226-7.

23 Mackenzie ET, McCulloch J, O' Kean M, Pickard JD, Harper AM. Cerebral circulation and norepinephrine: relevance of the blood-brain barrier. Am J Physiol 1976; 231: 483-8.

24 Newberg LA, Milde JH, Michenfelder JD. The cerebral metabolic effects of isoflurane at and above concentrations that suppress cortical electrical activity. Anesthesiology 1983; 59: 23-8.

25 Vernhiet J, Renou AM, Orgogozo JM, Constant $P$, Caille $J M$. Effects of a diazepam-fentanyl mixture on cerebral blood flow and oxygen consumption in man. $\mathrm{Br} \mathrm{J}$ Anaesth 1978; 50: 165-9. 